\title{
Agrimonia procera exerts antimicrobial effects, modulates the expression of defensins and cytokines in colonocytes and increases the immune response in lipopolysaccharide-challenged piglets
}

Tobias Gräber', Holger Kluge', Sebastian Granica², Gert Horn³, Jutta Kalbitz ${ }^{4}$, Corinna Brandsch', Antje Breitenstein ${ }^{4}$, Christine Brütting ${ }^{1}$ and Gabriele I. Stangl ${ }^{1 *}$ (D)

\begin{abstract}
Background: Because antibiotic use in livestock is assumed to contribute to the emerging public health crisis of antibiotic resistance, alternatives are required. Phytogenic additives are extensively studied due to their antibiotic properties. Components of Agrimonia species have been reported as candidate antimicrobials that possess antioxidative and anti-inflammatory properties. We studied the impact of Agrimonia procera (AP) on the growth of selected strains of gut bacteria, the effect of AP on the mRNA abundance of genes involved in inflammation and bacterial defense in a colon carcinoma cell line, the effect of AP in piglets challenged with lipopolysaccharides, and the effect of AP on the growth performance of healthy piglets.

Results: The in vitro growth rate of different bacteria strains was negatively affected by AP, especially in Pediococcus pentosaceus and all tested E. coli strains. Stimulation of Caco-2 cells with TNFa resulted in elevated mRNA expression of CXCL1, IL-8 and GPX2. After pretreatment of cells with AP, stimulation of Caco-2 cells with TNFa still resulted in elevated mRNA expression of CXCL1 and IL-8 at all measured points in time. However, mRNA expression in AP-pretreated cells was lower after $6 \mathrm{~h}$ and $24 \mathrm{~h}$. In addition, expression of DEFB1 and GPX2 was significantly elevated after TNFa stimulation. In vivo, application of lipopolysaccharides induced significantly increased animal body temperatures. Piglets pretreated with AP prior to lipopolysaccharide application showed a faster and larger increase in body temperature than controls. In addition, piglets pretreated with AP appeared to release more TNFa than controls. In healthy piglets, AP treatment had no impact on growth performance parameters. Fecal dry matter and total plasma antioxidant capacity tended to be higher in piglets treated with AP than in control piglets ( $P=0.055$ and $P=0.087$, respectively).

Conclusions: AP has antimicrobial effects in vitro and stimulated the expression of proinflammatory cytokines in Caco-2 cells. The additive had no effect on growth in healthy piglets but increased the immune response in LPS-treated animals. In addition, AP appeared to have antioxidative effects in vivo. Therefore, AP merits testing as a future alternative to antibiotics in animal husbandry.
\end{abstract}

Keywords: Agrimonia procera, Agrimoniin, Caco-2, Cytokine expression, Growth performance, Lipopolysaccharides (LPS), Pig, TNFa

\footnotetext{
* Correspondence: gabriele.stangl@landw.uni-halle.de

${ }^{1}$ Institute of Agricultural and Nutritional Sciences, Martin Luther University

Halle-Wittenberg, Von-Danckelmann-Platz 2, 06120 Halle (Saale), Germany

Full list of author information is available at the end of the article
}

(c) The Author(s). 2018 Open Access This article is distributed under the terms of the Creative Commons Attribution 4.0 International License (http://creativecommons.org/licenses/by/4.0/), which permits unrestricted use, distribution, and reproduction in any medium, provided you give appropriate credit to the original author(s) and the source, provide a link to the Creative Commons license, and indicate if changes were made. The Creative Commons Public Domain Dedication waiver (http://creativecommons.org/publicdomain/zero/1.0/) applies to the data made available in this article, unless otherwise stated. 


\section{Background}

Diseases affecting livestock are normally associated with a negative impact on animal productivity. Maintenance of general health and prevention of infectious diseases are critically dependent on intestinal homeostasis and proper immune competence. Early in life, stress factors such as the hygiene status of the postweaning room, air quality, group size and other husbandry conditions [1], as well as the composition of the gut microflora [2], are critical factors that influence the susceptibility of pigs to gastrointestinal infections. Antibiotics are used to treat ill animals or a batch of animals when at least one is diagnosed with a bacterial infection. Because the use of antibiotics in livestock animals is suggested to play a major role in the emerging public health crisis of antibiotic resistance [3], alternatives are required. In an attempt to improve animal welfare, phytogenic additives are being extensively studied as an alternative to antibiotics due to their antibiotic properties $[4,5]$. Polyphenols or polyphenol-rich extracts derived from forage crops or medicinal plants also appear to be able to reduce or inhibit inflammatory processes in cells and experimental animals [6-11].

Components of Agrimonia species, members of the family Rosaceae, have been reported as candidate antibiotic feed additives that possess antioxidative and anti-inflammatory properties. Zhu et al. [12] identified five flavonoids from Agrimonia pilosa Ledeb. - taxifolin, catechin, hyperoxide, quercitrin and rutin - that are particularly effective against oxidative DNA damage. Recent data have shown that the polyphenolic fraction of Agrimonia eupatoria L. exerts anti-inflammatory activity in LPS-stimulated macrophages and in a mouse model of carrageenan-induced paw edema [13]. In humans, the consumption of tea made of A. eupatoria L. significantly elevated the total antioxidant capacity of plasma and significantly lowered the level of interleukin-6 [14]. Seeds from $A$. eupatoria have been reported as candidates for antibiotic use owing to their antibacterial properties [15]. This is the reason why traditional medicine uses $A$. eupatoria and other Agrimonia species for treatment of diarrhea [16]. In Europe, one of the most common Agrimonia species is Agrimonia procera Wallr. (AP). The major bioactive compounds found in this species are polyphenols such as flavonoids, mainly glycosides of luteolin and apigenin. AP also contains larger amounts of the bitter-tasting compound agrimoniin [17]. Recently, we were able to show that treatment of porcine peripheral blood monocytes with AP extract reduced the mRNA abundance of TNFo in cells challenged with LPS but not in unchallenged cells [18]. However, the available data do not allow a final evaluation of whether AP and its bioactive compounds could be used for the prevention and treatment of infectious diseases in pigs.

Therefore, the current studies aimed to elucidate (i) the impact of AP on the growth of selected strains of gut bacteria; (ii) the effect of AP on the mRNA abundance of genes involved in inflammation, bacterial defense and radical scavenging in a colon carcinoma cell line; (iii) the effect of AP in pigs challenged with LPS; and (iv) the effect of AP on the growth performance of healthy pigs.

\section{Results}

\section{Characterization of secondary plant compounds in Agrimonia procera}

The most prominent polyphenol in AP samples was agrimoniin, with a concentration of $27.9 \mathrm{mg}$ per $\mathrm{g}$ of dry matter (Table 1). The flavones apigenin and luteolin were found as glycosides and glucuronides, with a higher concentration of 7-O-glucuronides than of 7-O-glycosides (Table 1). The flavonol quercetin was detected only as glycosidic compound (quercitrin). Kaempferol and procyanidins could not be detected in AP.

\section{Antimicrobial efficacy test of Agrimonia procera}

The growth kinetics curves of E. coli DSM 6895, E. coli DSM 8703, E. coli DSM 1103, Lactobacillus casei, Pediococcus pentosaceus and Salmonella enterica ssp. enterica serotype Typhimurium, as measured by turbidity at $600 \mathrm{~nm}$, are shown in Fig. 1. After 3 h, growth inhibition was apparent in most of the AP-treated strains. After $5 \mathrm{~h} 30 \mathrm{~min}$, the growth rates of AP-treated E. coli strains and $P$. pentosaceus decreased to 57, 60 and $72 \%$ compared to the control. The growth inhibition of AP-treated Salmonella was considerably slower than that of $E$. coli.

The maximum effect of AP on the growth of Salmonella was observed after $6 \mathrm{~h}(-23 \%)$. In contrast, the growth rate of $L$. casei was hardly affected by AP.

Table 1 Analyzed content of agrimoniin and related polyphenols in Agrimonia procera plant (mean; $n=2$ )

\begin{tabular}{ll}
\hline & $\mathrm{mg} / \mathrm{g}$ dry matter \\
\hline Agrimoniin & 27.9 \\
Apigenin 7-O-glucuronide & 2.18 \\
Luteolin-7-O-glucuronide & 1.46 \\
Hyperoside & 0.38 \\
Apigenin 7-O-glucoside & 0.21 \\
Luteolin-7-O-glucoside & 0.17 \\
Quercitrin & 0.04 \\
\hline
\end{tabular}



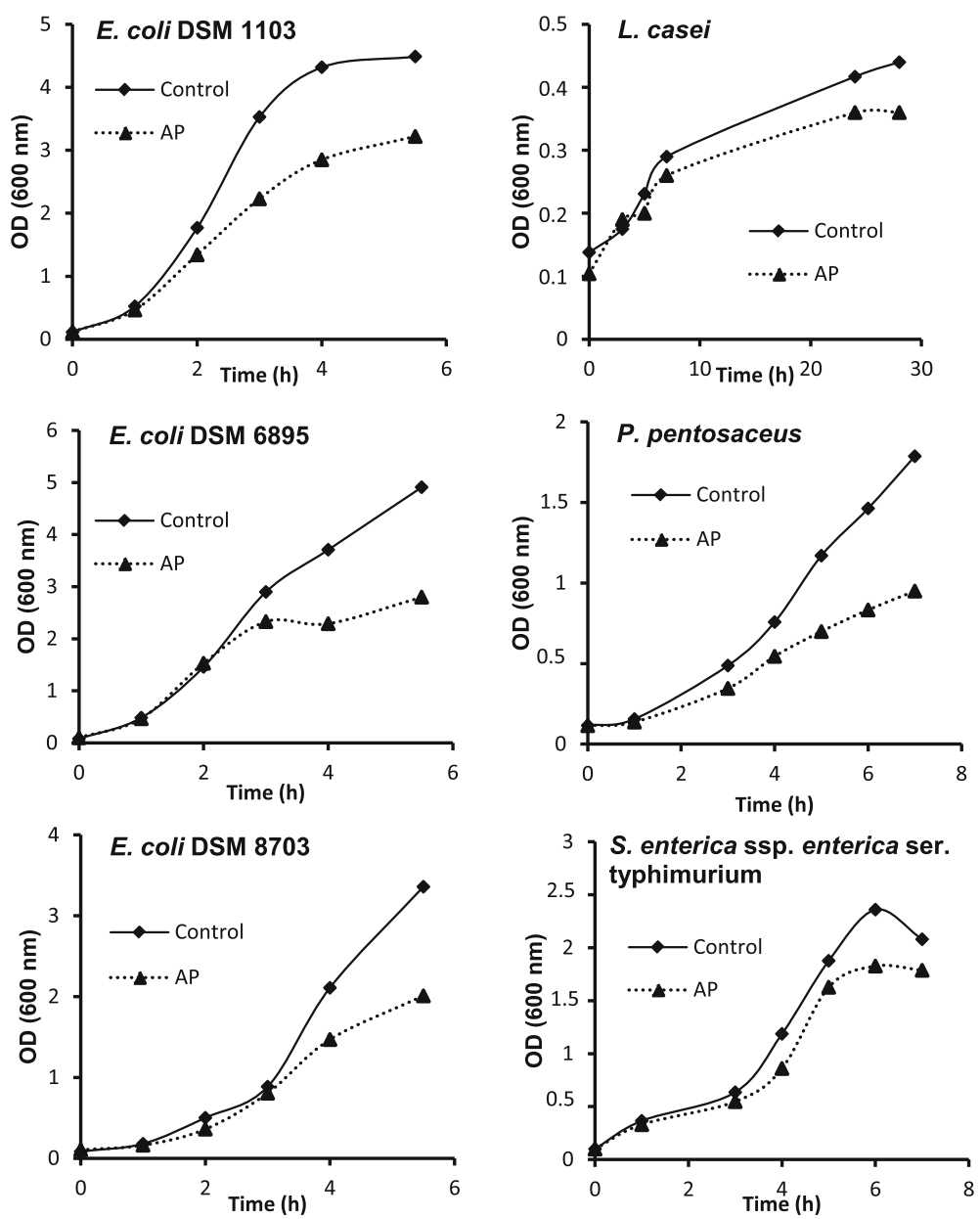

Fig. 1 Growth of bacterial strains with and without Agrimonia procera (AP). Growth of E. coli DSM 6895, E. coli DSM 8703, E. coli DSM 1103, Lactobacillus casei, Pediococcus pentosaceus and Salmonella enterica ssp. enterica serotype Typhimurium analyzed by assessing the optical density at $600 \mathrm{~nm}$ over a period of up to $28 \mathrm{~h}$. Different periods of examination are caused by different doubling times of bacterial strains. Bacterial strains were cultivated in medium at $37^{\circ}$ C with aqueous extracts of Agrimonia procera (AP, $1 \mathrm{mg} / \mathrm{ml}$ ). Medium without AP was used for the controls

In vitro experiments with Caco-2 cells

In the first experiment, we investigated the role of AP on gene expression in TNF $\alpha$-treated and untreated cells of the human colon carcinoma cell line Caco-2 (Fig. 2a). The second experiment aimed to investigate whether AP pretreatment induces cell conditions that influence the inflammatory response (Fig. 2b).

In the first experiment, stimulation of Caco- 2 cells with AP resulted in decreased expression of CXCL1 in TNF $\alpha$-treated cells and DEFB1 in TNF $\alpha$-treated and untreated cells; expression of IL-8 was increased in TNF $\alpha$-treated cells, expression of GPX2 was unaffected (Fig. 2a).

After cells were pretreated with AP, stimulation of Caco-2 cells with AP still resulted in decreased expression of CXCL1 in TNF $\alpha$-treated cells and DEFB1 in TNF $\alpha$-treated and untreated cells. Expression of GPX2 was increased in TNF $\alpha$-treated cells, expression of IL-8 was unaffected (Fig. 2b).
Performance parameters and selected clinical parameters of AP-treated piglets

In experiment 1 , the single LPS injection induced a rise in body temperature by more than $2{ }^{\circ} \mathrm{C}$ in both groups of piglets (Fig. 3). Piglets pretreated with AP prior to the LPS application showed a faster and a stronger increase in body temperature at some points in time than the control piglets (Fig. 3). However, AUC showed no difference between the two treatment groups $(p=0.5)$. Approximately $4.5 \mathrm{~h}$ after LPS injection, the body temperature of piglets started to decline in both groups. Analysis of plasma CRP before LPS injection and 6 and $24 \mathrm{~h}$ afterward revealed no difference between the two groups of piglets and no differences between the three analyzed points in time (Fig. 4a). Plasma TNF $\alpha$ concentration was markedly increased $1 \mathrm{~h}$ after LPS injection and declined afterwards, reaching its basal level 24 h after LPS injection (Fig. 4b). However, there were no differences in plasma TNF $\alpha$ concentration between the two groups of piglets. 

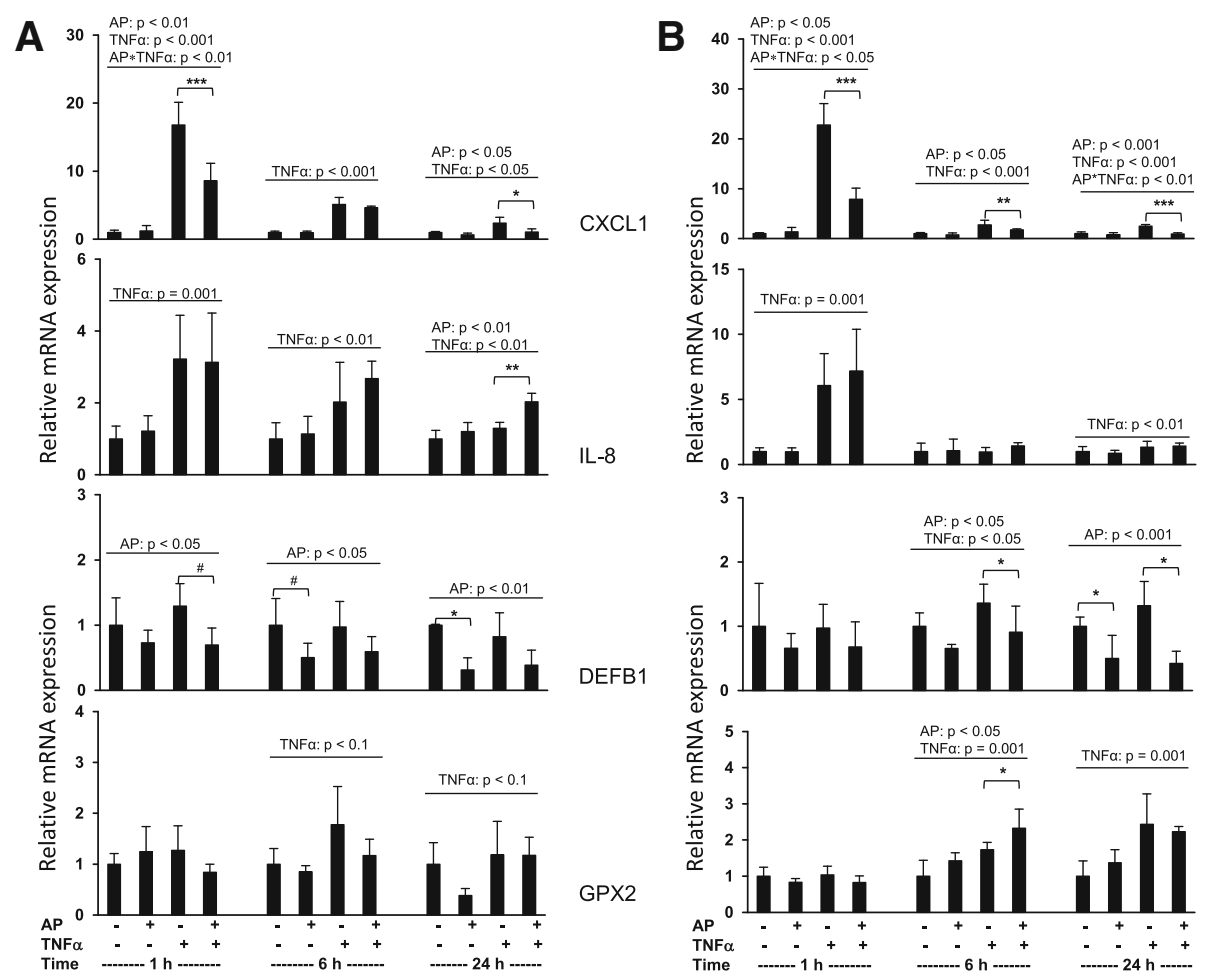

Fig. 2 Relative mRNA expression of defensins and cytokines in Caco-2 cells. Relative mRNA expression of chemokine (C-X-C motif) ligand (CXCL1), interleukin-8 (IL-8), beta-defensin 1 (DEFB1) and glutathione peroxidase 2 (GPX2) in Caco-2 cells a without agrimoniin (AP) pretreatment and $\mathbf{b}$ with AP pretreatment for $4 \mathrm{~h}$. Cells were coincubated with or without TNFa $(10 \mathrm{ng} / \mathrm{ml})$ and with or without AP $(50 \mu \mathrm{M})$ for $1 \mathrm{~h}, 6 \mathrm{~h}$ and $24 \mathrm{~h}$. Data represent the mean values $\pm \mathrm{SD}(1 \mathrm{~h}, 6 \mathrm{~h}, n=4 ; 24 \mathrm{~h}: n=3)$. Data were analyzed by two-way ANOVA with the classification factors AP and TNFa and the interaction between those two factors. Individual means at any given point in time were compared by Fisher's exact test. Differences between AP-treated (+) and non-AP-treated $(-)$ cells are indicated by asterisks: ${ }^{\#} p<0.1 ;{ }^{*} p<0.05 ;{ }^{* *} p<0.01 ;{ }^{* * *} p<0.001$

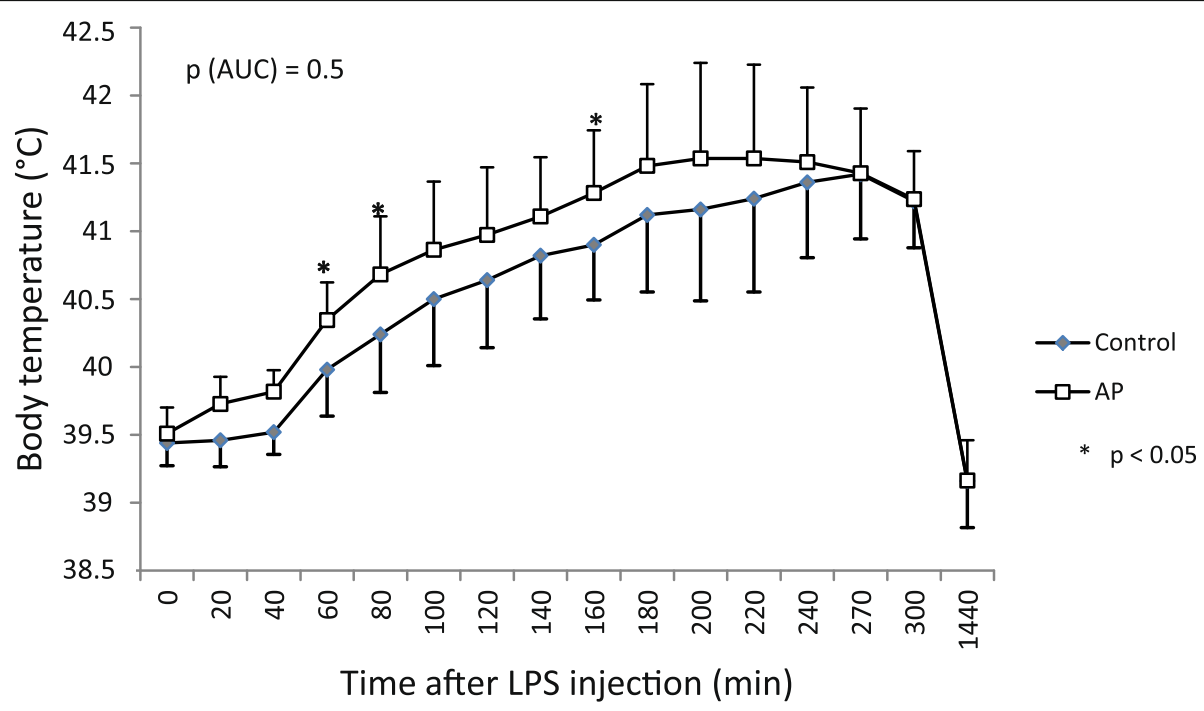

Fig. 3 Body temperature of piglets challenged with lipopolysaccharides (LPS). Body temperature $\left({ }^{\circ} \mathrm{C}\right.$ ) of piglets challenged with lipopolysaccharides (LPS) at a dose of $25 \mu \mathrm{g}$ per $\mathrm{kg}$ body weight i.p. Three weeks prior to the LPS treatment, the groups received a diet with Agrimonia procera powder (10 g/kg diet) or a diet without Agrimonia procera (control). Data represent the mean values and SD ( $n=11$ for the Agrimonia procera group; $n=5$ for the control group). AUC = area under the curve. ${ }^{*} p<0.05$ 


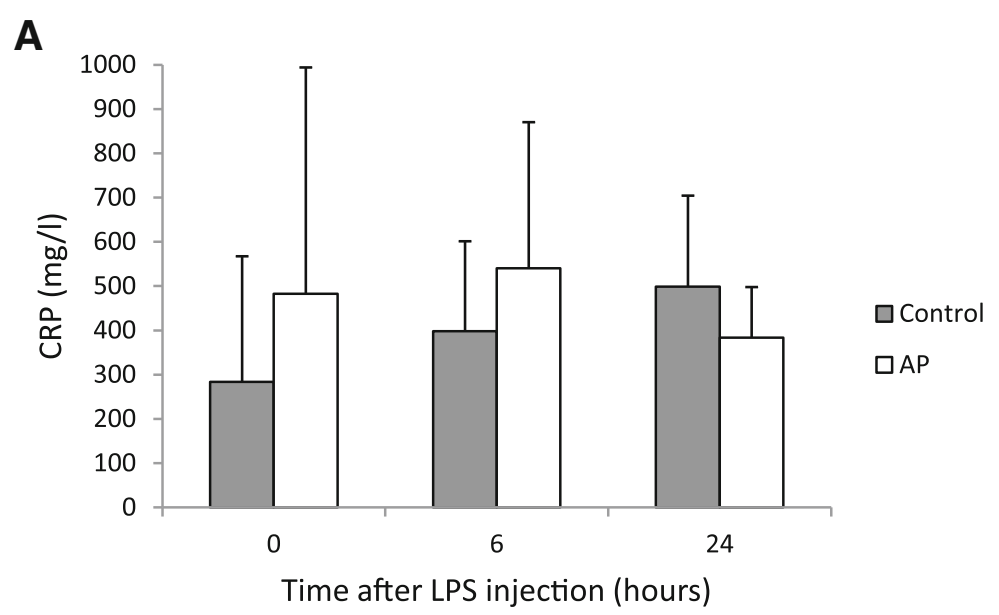

B

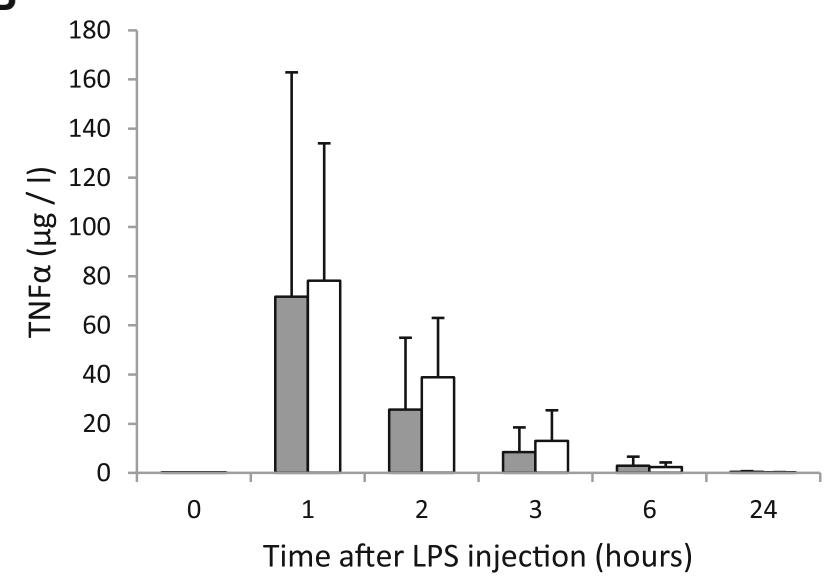

Fig. 4 Concentrations of CRP (a) and TNFa (b) in the plasma of piglets after LPS injection. Concentrations of CRP (a) and TNFa (b) in the plasma of piglets at different points in time after a single LPS injection $(25 \mu \mathrm{g} / \mathrm{kg}$ body weight i.p.). Piglets were fed diets without (control) or with Agrimonia procera (AP, $10 \mathrm{~g} / \mathrm{kg}$ diet) for 3 weeks before the challenge. Data represent the mean values and SD ( $n=12$ for the Agrimonia procera group; $n=5$ for the control group)

In experiment 2, food intake, final body weight, daily body weight gain and food conversion ratio did not differ among the three groups of piglets (Table 2). Likewise, no impact of AP was found on growth performance after the 23-day post-intervention period (Table 2). During the intervention period, the calculated AP intake per piglet was $1.1 \mathrm{~g} / \mathrm{d}$ in the AP1 group and $11.5 \mathrm{~g} / \mathrm{d}$ in the AP2 group. Analysis of feces after the intervention period at day 15 revealed that piglets treated with AP tended to have higher fecal dry matter than controls $(P=0.055)$. Correspondingly, the number of piglets with fecal dry matter $<15 \%$ was reduced in both AP groups compared to the control group (Table 2). The total antioxidant capacity of plasma, expressed as TEAC and assessed after the intervention period, tended to be higher in piglets treated with AP than in control piglets $(P=0.087$, Table 2$)$.

\section{Discussion}

The aim of the study was to elucidate the antimicrobial and antioxidant properties as well as the immunomodulatory effects of AP in vivo and in vitro.

The growth rates of various bacterial strains, especially Pediococcus pentosaceus and all tested E. coli strains, were reduced by AP in vitro (Fig. 1). This is of special interest, as, during the first few weeks after weaning, most diseases (such as diarrhea) are caused by E. coli $[19,20]$. E. coli colonizes the small intestine and produces toxins that impair intestinal barrier function, stimulate intestinal water influx [21] and reduce the growth of beneficial bacteria $[22,23]$. Bacterial diarrhea also increases the release of reactive oxygen species in immune cells [24]. The performance-enhancing effect of phytogenic additives in pigs [25] and poultry [26] is caused by a stabilization of the intestinal flora and thus constitutes even more than a direct antimicrobial effect. 
Table 2 Growth performance and health parameters of piglets fed Agrimonia procera compared to control piglets

\begin{tabular}{|c|c|c|c|}
\hline \multirow[t]{2}{*}{ Parameters } & \multirow{2}{*}{$\begin{array}{l}\text { Control } \\
(0 \mathrm{~g} / \mathrm{l})\end{array}$} & \multicolumn{2}{|c|}{ Agrimonia procera (AP) } \\
\hline & & $\overline{\mathrm{AP} 1}(1 \mathrm{~g} / \mathrm{l})$ & AP2 $(10 \mathrm{~g} / \mathrm{l})$ \\
\hline \multicolumn{4}{|l|}{ Mean feed intake $(\mathrm{g} / \mathrm{d})^{a}$} \\
\hline Intervention period (days 1-15) & $220 \pm 28$ & $199 \pm 13$ & $239 \pm 37$ \\
\hline Follow-up period (days 15-38) & $814 \pm 91$ & $810 \pm 16$ & $860 \pm 2$ \\
\hline \multicolumn{4}{|l|}{ Body weight (kg) } \\
\hline End of intervention period (day 15) & $10.9 \pm 2.3$ & $10.7 \pm 1.8$ & $11.0 \pm 1.8$ \\
\hline End of follow-up period (day 38) & $23.7 \pm 3.2$ & $23.4 \pm 3.3$ & $24.4 \pm 2.6$ \\
\hline \multicolumn{4}{|l|}{ Daily weight gain (g/d) } \\
\hline Intervention period (days 1-15) & $157 \pm 77$ & $155 \pm 64$ & $175 \pm 76$ \\
\hline Follow-up period (days 15-38) & $550 \pm 59$ & $554 \pm 85$ & $566 \pm 72$ \\
\hline \multicolumn{4}{|l|}{ Feed conversion ratio ${ }^{a}$} \\
\hline Intervention period (days 1-15) & $1.42 \pm 0.03$ & $1.29 \pm 0.15$ & $1.37 \pm 0.12$ \\
\hline Follow-up period (days 15-38) & $1.48 \pm 0.13$ & $1.46 \pm 0.02$ & $1.52 \pm 0.01$ \\
\hline Fecal dry matter content (\%) at day 15 & $19.8 \pm 8.1$ & $22.2 \pm 6.1$ & $24.8 \pm 3.4$ \\
\hline \multicolumn{4}{|l|}{ Number of piglets with fecal dry matter } \\
\hline$<15 \%$ at day 15 & 6 & 3 & 1 \\
\hline Plasma $\operatorname{TEAC}^{\mathrm{b}}(\mu \mathrm{mol} / \mathrm{ml})$ at day 15 & $6.28 \pm 0.86$ & $6.53 \pm 0.97$ & $7.22 \pm 0.86$ \\
\hline
\end{tabular}

Growth performance and health parameters of piglets fed Agrimonia procera compared to controls for 15 days with a follow-up period of 23 days. Data are means and standard deviations $(n=20)$

a Means of 2 piglets per pen

${ }^{\mathrm{b}}$ TEAC Trolox equivalent antioxidant capacity

Oligomeric polyphenols (such as agrimoniin) transit the gastrointestinal tract without being altered and are only marginally transported across the intestinal epithelium [27-29]. Accordingly, polyphenols have a direct effect on harmful and toxic bacteria such as various Salmonella and E. coli species. Furthermore, polyphenols reaching the colon are extensively metabolized by the microflora into a wide range of low-molecular-weight phenolic acids. Accordingly, polyphenols may have a favorable effect on the gut microflora, as shown in animals [30, 31] and humans [32]. For example, polyphenols from black tea have been shown to reduce the prevalence of diarrhea by up to $20 \%$ in piglets orally infected with E. coli [33]. Black tea extract has been shown to improve net fluid absorption after infection and has an inhibitory capacity towards enterotoxigenic pathogens and their enterotoxins [34]. The literature presents various explanations for the antidiarrheal effect of AP (e.g., $[35,36])$. First, the phenolic compound could bind to iron, thereby rendering the mineral unavailable to $E$. coli and consequently delaying its growth. Second, the potential formation of complexes with bacterial cell membrane proteins or polysaccharides could disrupt cell membrane integrity and growth. Another possibility is that AP phenolic compounds bind to enterotoxin and thereby inhibit enterotoxin internalization. As agrimoniin also showed potent inhibitory effects on 32 tested Helicobacter pylori strains [37] and Staphylococcus aureus [38], the antimicrobial efficacy of AP seems to have a broad spectrum.

In the next step, we analyzed the impact of AP on the expression of relevant defense proteins in TNF $\alpha$-treated and untreated enterocytes in vitro using Caco- 2 cells. Caco- 2 cells are accepted as in vitro model of the intestinal epithelium and are therefore suitable to study the anti-inflammatory potential of AP. Moreover, Caco-2 cells and IPEC-J2 intestinal porcine epithelial cells show equal responses to inflammation and the added ingredients [39].

In the current study, stimulation of Caco-2 cells with AP resulted in decreased expression of CXCL1 in TNF $\alpha$-treated cells.

Generally, polyphenols are able to modulate NF- $\mathrm{B}$ B and mitogen-activated protein kinase activation after oral administration [40]. Agrimoniin has been shown to inhibit TNF $\alpha$-induced NF- $\mathrm{KB}$ driven transcription and nuclear translocation in a concentration-dependent manner in human gastric epithelial cells [41]. Presumably, certain oligomeric polyphenols induce anti-inflammatory effects in Caco-2 cells via direct interaction with TNF $\alpha$ receptors or via interactions with membrane lipids, leading to changes in the physical properties of the membrane that affect the affinity of the receptor for its ligand $[42,43]$. The current in vitro experiment shows that cells treated simultaneously with TNF $\alpha$ and AP are characterized by increased expression of the proinflammatory cytokine IL-8. This is 
an unexpected finding, as polyphenols are usually described as anti-inflammatory molecules [41, 44]. On the other hand, an effective immune response to bacteria requires the activation of NF- $\mathrm{kB}$ to produce cytokines.

Expression of DEFB1 was significantly lower in cells treated with AP than in cells without AP treatment, independent of the presence of TNF $\alpha$. Defensins, typically termed antimicrobial peptides, are important components of host defense through innate immunity. Therefore, defensins are promising candidates for use as antibiotics [45]. In addition, defensins affect the activation of NF-kB [46].

AP also had significant effects on the mRNA expression of GPX2 in cells pretreated with AP. TNF $\alpha$-challenged cells treated with AP had significantly higher GPX2 expression than cells without AP treatment. GPX2 was identified to be involved in the activation of the endogenous antioxidant defense system in Caco-2 cells [47] and is a target gene of Nrf2. Certain isolated phytochemicals inhibit the NF- $\mathrm{KB}$ pathway and simultaneously activate the Nrf2 pathway [10]. Moreover, there is a significant correlation between TEAC and estimated phenolic content. This anti-inflammatory activity suggests a contributory role of polyphenols in the anti-inflammatory activity of several culinary herbs that have been investigated [44].

Most gram-negative bacteria, such as E. coli, have LPS as an intrinsic component of the outer membrane. This component activates the immune system and stimulates the expression of proinflammatory cytokines, such as TNF $\alpha$ [48]. Therefore, the anti-inflammatory potential of AP was investigated in vivo in LPS-challenged animals.

Application of LPS induced significantly elevated body temperatures in animals. The AUC of body temperature showed no difference between the treatment and control groups, whereas piglets pretreated with AP prior to LPS application showed faster and larger increases in body temperature than control piglets at some points in time (Fig. 3). In addition, piglets pretreated with AP appeared to release more TNFa than controls (Fig. 4). Although treatment with LPS does not completely mimic the physiological effects of infection and inflammation in commercial practice $[49,50]$ as, e.g., LPS and living $E$. coli induce different immunological profiles in weaned pigs [51], previous studies advanced the concept that pigs injected with LPS could imitate the response of piglets exposed to microorganisms in a conventional environment [52, 53]. In pigs, LPS evokes a rapid febrile response, reduces feed intake and increases plasma TNF $\alpha[54,55]$. Fever decreases the toxicity and growth of bacteria, boosts the immune system, inhibits LPS formation and increases survival rates [56-58]. Herbal extracts can stimulate the immune system $[59,60]$. After 5 weeks of dietary supplementation with polyphenol-rich cereals, leukocyte functions were improved [61]. Intraperitoneal injection of agrimoniin increased the number of peripheral white blood cells and the ratio of monocytes in rodents [62], and A. eupatoria tea consumption led to decreased interleukin 6 levels in humans [14]. Moreover, agrimoniin-containing Potentilla erecta showed significant erythema-reducing activity in vivo [63].

As different herbs were also shown to improve growth performance parameters in piglets $[64,65]$, we analyzed the impact of AP on growth performance.

AP treatment had no impact on the analyzed growth performance parameters in piglets (Table 3). Only fecal dry matter and total plasma antioxidant capacity tended to be higher in piglets treated with AP than in control

Table 3 Characteristics of primer sequences used for quantitative real-time RT-PCR analysis

\begin{tabular}{|c|c|c|c|}
\hline Gene & $\begin{array}{l}\text { Forward primer (from } 5^{\prime} \text { to } 3^{\prime} \text { ) } \\
\text { Reverse primer (from } 5^{\prime} \text { to } 3^{\prime} \text { ) }\end{array}$ & Product size (bp) & NCBI GenBank number \\
\hline \multirow[t]{2}{*}{ CXCL1 } & ATGCTGAACAGTGACAAATC & 96 & NM_001511.3 \\
\hline & TCTTCTGTTCCTATAAGGGC & & \\
\hline \multirow[t]{2}{*}{ |L-8 } & GTIITGAAGAGGGCTGAG & 89 & NM_000584.4 \\
\hline & TाTGCTTGAAGTTTCACTGG & & \\
\hline \multirow[t]{2}{*}{ GPX2 } & AATTTGGACATCAGAACTGC & 190 & NM_001115136.1 \\
\hline & GGCTGCTCTTCAAGATTTAG & & \\
\hline \multirow[t]{2}{*}{ DEFB1 } & AGGTGGTAACTTTCTCACAG & 192 & NM_005218.3 \\
\hline & AAGTTCATTTCACTTCTGCG & & \\
\hline \multirow[t]{2}{*}{ GAPDH } & GACCACAGTCCATGCCATCAC & 453 & NM_002046.5 \\
\hline & TCCACCACCCTGTTGCTGTAG & & \\
\hline \multirow[t]{2}{*}{ RPLPO } & TCGACAATGGCAGCATCTAC & 223 & NM_001002.3 \\
\hline & GCCTTGACCTTTCAGCAAG & & \\
\hline
\end{tabular}


piglets (Table 3). Additionally, A. eupatoria L. failed to affect the growth performance of farm animals [66]. In contrast, AP had a positive effect on nitrogen retention and food conversion ratio [18]. Antioxidant effects were also found in other studies [67]. The inconsistent results could be explained by variation in the composition of phytobiotics. The potency of medical plants depends on factors such as growing location, harvest conditions, extraction and stabilization methods, and storage conditions [68].

\section{Conclusions}

The current studies showed that AP exerted antimicrobial effects in vitro, as the growth rate of various bacteria strains was negatively affected. Interestingly, the additive showed inflammatory potential in vitro and increased the immune response in LPS-treated animals. In addition, AP appeared to exert antioxidative effects in vivo. As an effective immune response to bacteria requires the activation of NF-kB to produce cytokines, AP has the future potential to function as an effective alternative to antibiotics in animal husbandry. Therefore, prospective studies should focus on animal experiments showing that AP-pretreated animals are in fact able to respond more rapidly and appropriately to a bacterial infection than non-treated control animals.

\section{Methods}

\section{Characterization of secondary plant compounds in Agrimonia procera}

Flavonoids and agrimoniin were extracted from AP (aerial parts, harvested in 2011 in Zappendorf and milled to pass through a $1 \mathrm{~mm}$ sieve) with ethanol $(50 \%)$ in an ultrasonic bath for $10 \mathrm{~min}$ at $30{ }^{\circ} \mathrm{C}$. After centrifugation at $450 \mathrm{rpm}$ for $10 \mathrm{~min}$, the supernatant was analyzed by HPLC using an Agilent 1100 system (Agilent, Santa Clara, USA) equipped with an UV detector. For flavonoid analysis, a reversed-phase column (Kinetex ${ }^{\oplus}, 5 \mu \mathrm{m} \mathrm{C18}, 150 \times 4.6 \mathrm{~mm}^{2}$ ) and a guard column (Security Guard Ultra, both Phenomenex, Aschaffenburg, Germany) were used. The mobile phase consisted of (A) water $+0.1 \%$ trifluoracetic acid and (B) acetonitrile $+0.1 \%$ trifluoracetic acid (time table: from A/B 90:10 to 60:40 in $30 \mathrm{~min}$ ). For agrimoniin analysis, a reversed-phase column (Luna ${ }^{\oplus} 3 \mu \mathrm{m} \operatorname{PEP}(2), 150 \times 4.6 \mathrm{~mm}^{2}$ ) and a C18 guard column (both Phenomenex) were used. The mobile phase consisted of (A) water:methanol:formic acid (95:6:0.1, $v / v / v)$ and (B) methanol:formic acid (100:0.1, v/v) (time table: from A/B 95:5 to 5:95 in $38 \mathrm{~min}$ ). In both analyses, the flow rate was $1 \mathrm{ml} / \mathrm{min}$ and the injection volume was $5 \mu \mathrm{l}$. P-aminobenzoic acid was used as an internal standard.

\section{Antimicrobial efficacy test of Agrimonia procera}

The potential antibacterial effects of AP were elucidated by treating Escherichia (E.) coli strains (DSM 1103, DSM 6895, DSM 8703), Salmonella (S.) enterica ssp. enterica serotype Typhimurium (ATCC 13311) and the lactic acid bacteria Lactobacillus (L.) casei (DSM 20011) and Pediococcus pentosaceus (DSM 20336) with an aqueous extract of AP. The strains were obtained from German Culture Collection (DSMZ, Braunschweig, Germany). To this end, bacterial strains were initially cultivated in LB medium (Carl Roth, Karlsruhe, Germany) for E. coli, CASO-Bouillon (Carl Roth) for S. enterica ssp. enterica ser. Typhimurium, and MRS medium (Carl Roth) for $L$. casei and Pediococcus pentosaceus at $37{ }^{\circ} \mathrm{C}$ on a shaker at $150 \mathrm{rpm}$ (Infors, Bottmingen, Schweiz). To produce the aqueous extract of AP, we infused $1.5 \mathrm{~g}$ of AP powder (Exsemine $\mathrm{GmbH}$, Salzatal, Germany) in $150 \mathrm{ml}$ of boiling water for $30 \mathrm{~min}$. Aliquots of the aqueous extract were then added to the respective media to yield a concentration of $1 \mathrm{mg}$ of AP aqueous extract per ml. After cooling, the test media were filtrated with a $0.2 \mu \mathrm{m}$ syringe filter under sterile conditions and inoculated with the bacteria strains. The growth of bacteria was estimated by measuring the optical density at $600 \mathrm{~nm}$ over a period of up to $28 \mathrm{~h}$. Due to the different growth rates of the bacterial strains, the investigation periods for the response of bacterial strains to AP varied. The control groups used the same media without AP.

\section{In vitro experiments with Caco-2 cells}

To elucidate the effects of agrimoniin on mRNA expression of inflammatory molecules and host defense peptides in enterocytes, we employed the human colon carcinoma cell line Caco-2. Cells were grown in MEM (Life Technologies, Darmstadt, Germany) supplemented with $10 \%$ fetal bovine serum (FBS, Life Technologies), $1 \%$ nonessential amino acids (PAA, Pasching, Austria) and $0.5 \%$ gentamicin (Life Technologies). Cells were maintained at $37{ }^{\circ} \mathrm{C}$ in a humidified atmosphere with $5 \%$ $\mathrm{CO}_{2}$. The medium was changed every 2 days. The cells were cultivated in culture flasks (Greiner, Frickenhausen, Germany) and passaged regularly before reaching confluence. For treatment, cells were seeded in 24-multiwell plates (Greiner) at a density of $1 \times 10^{5}$ cells per $\mathrm{ml}$ of medium per well, cultured to confluence, and then cultured for an additional 6 days.

Two cell experiments were conducted, both employing a two-factor design with the treatment factors agrimoniin and TNF $\alpha$. In the first experiment, cells were simultaneously treated with 0 or $10 \mathrm{ng} / \mathrm{ml}$ TNF $\alpha$ (R\&D Systems, Abingdon, UK) and 0 or $50 \mu \mathrm{M}$ agrimoniin for 1,6 and $24 \mathrm{~h}$.

The second experiment aimed to investigate whether agrimoniin pretreatment induces cell conditions that 
modulate their inflammatory response. To this end, cells were preincubated with 0 and $50 \mu \mathrm{M}$ agrimoniin for $4 \mathrm{~h}$. Thereafter, the preincubation medium was removed and replaced with fresh medium containing 0 or $10 \mathrm{ng} / \mathrm{ml}$ TNF $\alpha$ and 0 or $50 \mu \mathrm{M}$ agrimoniin for 1,6 and $24 \mathrm{~h}$. The AP powder used for both experiments was dissolved in DMSO (Sigma), TNF $\alpha$ was dissolved in PBS. Cells treated with TNF $\alpha$ - and agrimoniin-free medium made up the control groups. The media for the controls contained corresponding volumes of DMSO $(<0.1 \%)$ and PBS in place of TNF $\alpha$ and agrimoniin, respectively.

At the end of each experiment, the supernatants were removed, and the cells were frozen and stored at $-80{ }^{\circ} \mathrm{C}$ until analysis of mRNA expression of chemokine (C-X-C motif) ligand (CXCL1), interleukin-8 (IL-8), glutathione peroxidase 2 (GPX2), and beta-defensin 1 (DEFB1). Each experiment was repeated 3 times.

\section{Real-time RT-PCR analysis}

Total RNA was isolated from Caco-2 cells using peqGOLD TriFast $^{\text {tux }}$ (Peqlab, Erlangen, Germany) according to the manufacturer's protocol. RNA concentration and purity were determined by optical density at 260 and $280 \mathrm{~nm}$, respectively, using a spectrophotometer. Total RNA $(1.2 \mu \mathrm{g})$ was subjected to first-strand cDNA synthesis at $42{ }^{\circ} \mathrm{C}$ for $60 \mathrm{~min}$ using M-MuLV RT (Thermo Fisher Scientific Inc., Waltham, MA, USA) and oligo dT18-primer (Operon Biotechnologies, Cologne, Germany). The mRNA concentrations of reference and target genes were measured with real-time detection PCR using SYBR ${ }^{\circ}$ Green I (Sigma-Aldrich $\mathrm{GmbH}$ ) and the Rotor-Gene 2000 system (Corbett Research, Mortlake, Australia) to determine the relative mRNA concentrations of the target genes. PCR was performed with $0.5 \mathrm{U}$ of GoTaq Flexi DNA polymerase (Promega, Mannheim, Germany), $200 \mu \mathrm{M}$ dNTP (Ares Bioscience, Cologne, Germany) and 26.7 pmol of the specific primers (Operon Biotechnologies). For determination of relative mRNA expression, a threshold cycle $\left(C_{t}\right)$ was obtained from each amplification curve using the software Rotor-Gene 4.6 (Corbett Research). The housekeeping genes glyceraldehyde 3-phosphate dehydrogenase (GAPDH) and ribosomal phosphoprotein P0 (RPLP0) were applied for normalization; both showed high stability. Relative mRNA concentration was calculated according to Pfaffl [69]. The amplification and specificity of PCR products were controlled with agarose gel electrophoresis. The characteristics of the primers used are shown in Table 3.

\section{Performance and selected clinical parameters of AP- treated piglets}

Animal experiments were conducted using weaned hybrid piglets [(German Landrace $\times$ German Edelschwein $) \times$
Pietrain]. All animals were kept in an environmentally controlled facility with light from 6:00 am to $6: 00 \mathrm{pm}$, relative humidity between 55 and $60 \%$, and a temperature of $29^{\circ} \mathrm{C}$ at the beginning, which was decreased gradually to $22{ }^{\circ} \mathrm{C}$ at the end of the experiments. Both studies were approved by the local Animal Care and Use Committee of the council of Saxony-Anhalt (Landesverwaltungsamt Sachsen-Anhalt, Germany; approval number of the first animal trial: 42502-2-1143MLU; approval number of the second animal trial: 42502-3-716MLU).

The first experiment was conducted to elucidate the response of LPS-challenged piglets to AP treatment. Twelve castrated 7-week-old male piglets were assigned to 2 groups of 6 animals each. The piglets were housed individually in cages and received a basal diet that contained the following (per $\mathrm{kg}$ ): $380 \mathrm{~g}$ of wheat, $195 \mathrm{~g}$ of barley, $180 \mathrm{~g}$ of soybean meal, $100 \mathrm{~g}$ of corn, $50 \mathrm{~g}$ of whey powder, $30 \mathrm{~g}$ of wheat bran, $25 \mathrm{~g}$ of soybean oil, and $40 \mathrm{~g}$ of standard premix to meet the nutrient requirements for piglets [70] supplemented with either $0 \mathrm{~g}$ (control) or $10 \mathrm{~g}$ of AP powder (dried and ground aerial parts of AP) per $\mathrm{kg}$ of diet for 3 weeks. After this 3-week-period, the piglets were challenged with a single LPS treatment. Specifically, $25 \mu \mathrm{g}$ of LPS per $\mathrm{kg}$ of body weight was injected intraperitoneally after the diets were delivered at 8:00 a.m. LPS (from E. coli 0111:B4, Sigma-Aldrich L-2630, Munich, Germany) was dissolved at $250 \mu \mathrm{g} / \mathrm{ml}$ in physiological saline solution. On the day of injection, the piglets had a mean body weight of $15.7 \mathrm{~kg}$. After LPS injection, the piglets were clinically monitored for a period of $24 \mathrm{~h}$. Rectal temperature was measured with a digital thermometer every 20 min during the first $5 \mathrm{~h}$ and at the end of $24 \mathrm{~h}$. Blood samples were collected from the jugular vein immediately prior to LPS administration $(0 \mathrm{~h})$ and $1,2,3,6$, and $24 \mathrm{~h}$ afterwards to analyze the plasma concentrations of C-reactive protein (CRP) and TNF $\alpha$.

In the second experiment, we aimed to investigate the effects of AP in apparently healthy piglets. For that purpose, sixty castrated 4-week-old male and female (1:1) piglets with a mean body weight of $8.5 \mathrm{~kg}$ were randomly assigned to 3 groups of 20 animals each (10 male and 10 female). Two groups received AP as an aqueous extract containing $1 \mathrm{~g}$ or $10 \mathrm{~g}$ of AP per liter for 15 days. The third group received no AP extract and served as a control. All groups received the basal diet mentioned above. The aqueous AP extract was prepared by infusing dried AP (Exsemine GmbH, Salzatal, Germany) in hot water for $10 \mathrm{~min}$ with subsequent filtration. The piglets were housed in flat-deck pens (10 piglets per pen) and had free access to food and water. Blood samples were drawn from the jugular vein to analyze antioxidant activity in plasma at the beginning and the end of the experiment. Feces samples were collected and assessed for 
their dry matter content (on day 15). The intake of food and aqueous AP extract was recorded daily; body weights were recorded weekly. The performance data were also assessed for a postexperimental period of 23 days.

\section{Analysis of plasma TNFa, CRP and antioxidant capacity}

TNF $\alpha$ and CRP concentrations in plasma were determined by using an ELISA kit (R\&D systems, Minneapolis, USA). The antioxidant capacity of plasma was assessed by using a Trolox equivalent antioxidant capacity (TEAC) assay as described elsewhere [18].

\section{Statistical analysis}

Data collected from Caco-2 cell experiments were analyzed with two-way ANOVA. The effects of the two factors agrimoniin $(0$ vs. $50 \mu \mathrm{M})$ and TNF $\alpha(0$ vs. $10 \mathrm{ng} / \mathrm{ml})$ as well as their interaction were investigated. When two-way ANOVA revealed a significant effect, a post hoc comparison was performed. In the case of variance homogeneity, the means of the four treatment groups were compared by Fisher's exact test. In the case of variance heterogeneity, the Games-Howell test was applied. Means were considered significantly different at $P<0.05$. In the first animal experiment, the means of the two groups were compared by Student's t-test. For body temperature, the area under the curve (AUC) was calculated for each piglet, and treatment groups were compared by means of Student's t-test. Data obtained from the second animal experiment were analyzed by one-way ANOVA (Minitab, Version 13, State College, PA, USA). In the case of significant $\mathrm{F}$-values $(\mathrm{P}<0.05)$, means were compared by the Fisher's least significant difference (LSD) test.

\section{Abbreviations}

AP: Agrimonia procera; AUC: Area under the curve; CXCL1: Chemokine (C-X-C motif) ligand 1; DEFB1: Beta-defensin 1; GPX2: Glutathione peroxidase 2; IL8: Interleukin-8; LPS: Lipopolysaccharide; NF-kB: Nuclear factor-kappa B;

TNF: Tumor necrosis factor

\section{Acknowledgements}

This work was supported by The Deutsche Bundesstiftung Umwelt (DBU), reference number 27074-34.

\section{Funding}

This work was supported by The Deutsche Bundesstiftung Umwelt (DBU), reference number 27074-34

\section{Availability of data and materials}

The datasets used and analyzed during the current study are available from the corresponding author on reasonable request.

\section{Authors' contributions}

$\mathrm{TG}, H \mathrm{~K}, \mathrm{SG}$ and GIS designed the study; GH provided the Agrimonia powder; TG, HK and CB conducted the experiment; TG, JK and CB conducted the analyses; $A B$ conducted the antimicrobial tests; TG, HK, CB and ChB performed statistical analyses and interpreted the data; $\mathrm{TG}, \mathrm{HK}$ and $\mathrm{ChB}$ wrote the paper with input from all authors. All authors read and approved the final manuscript.

\section{Ethics approval}

The animal studies complied with national guidelines, and have been approved by the local Animal Care and Use Committee of the council of Saxony-Anhalt (Landesverwaltungsamt Sachsen-Anhalt, Germany; approval number of the first animal trial: 42502-2-1143MLU; approval number of the second animal trial: 42502-3-716MLU).

The animals used were research animals born in the research facility. After the studies all animals stayed within the research facility until they have been sold to an agricultural cooperative.

\section{Consent for publication}

Not applicable.

\section{Competing interests}

The authors declare that they have no competing interests.

\section{Publisher's Note}

Springer Nature remains neutral with regard to jurisdictional claims in published maps and institutional affiliations.

\section{Author details}

${ }^{1}$ Institute of Agricultural and Nutritional Sciences, Martin Luther University Halle-Wittenberg, Von-Danckelmann-Platz 2, 06120 Halle (Saale), Germany. ${ }^{2}$ Department of Pharmacognosy and Molecular Basis of Phytotherapy, Faculty of Pharmacy, Medical University of Warsaw, Banacha St. 1, 02-097 Warsaw, Poland. ${ }^{3}$ Exsemine $\mathrm{GmbH}$, Am Wehr 4, 06198 Salzatal, Germany. ${ }^{4}$ BioSolutions Halle GmbH, Weinbergweg 22, 06120 Halle (Saale), Germany.

Received: 28 August 2018 Accepted: 31 October 2018

Published online: 15 November 2018

\section{References}

1. Madec F, Bridoux N, Bounaix S, Jestin A. Measurement of digestive disorders in the piglet at weaning and related risk factors. Prev Vet Med. 1998;35:5372 .

2. Schocker D, Zhang J, Zhang LL, Vastenhouw SA, Heilig HG, Smidt H, et al. Early-life environmental variation affects intestinal microbiota and immune development in new-born piglets. PLoS One. 2014;9:e100040.

3. Landers TF, Cohen B, Wittum TE, Larson EL. A review of antibiotic use in food animals: perspective, policy, and potential. Pub Health Rep. 2012:127:4-22.

4. Hashemi SR, Zulkifli I, Hair Bejo M, Farida A, Somchit MN. Acute toxicity study and phytochemical screening of selected herbal aqueous extract in broiler chickens. Int J Pharmacol. 2008;4:352-60.

5. Huang Q, Liu X, Zhao G, Hu T, Wang Y. Potential and challenges of tannins as an alternative to in-feed antibiotics for farm animal production. Anim Nutr. 2017:4:137-50.

6. Romier B, Schneider YJ, Larondelle Y. During a dietary polyphenols can modulate the intestinal inflammatory response. Nutr Rev. 2009;67:363-78.

7. Biasi F, Astegiano M, Maina M, Leonarduzzi G, Pol G. Polyphenol supplementation as a complementary medicinal approach to treating inflammatory bowel disease. Curr Med Chem. 2011;18:4851-65.

8. González R, Ballester I, López-Posadas R, Suárez MD, Zarzuelo A, MartinezAugustin $\mathrm{O}$, et al. Effects of flavonoids and other polyphenols on inflammation. Crit Rev Food Sci. 2011;51:331-62.

9. Song YA, Park YL, Yoon SH, Kim KY, Cho SB, Lee WS, et al. Black tea polyphenol theaflavin suppresses LPS-induced ICAM-1 and VCAM-1 expression via blockage of NF-KB and JNK activation in intestinal epithelial cells. Inflamm Res. 2011;60:493-500.

10. Gessner DK, Ringseis R, Siebers M, Keller J, Kloster J, Wen G, et al. Inhibition of the pro-inflammatory NF-KB pathway by a grape seed and grape marc meal extract in intestinal epithelial cells. J Anim Physiol An N. 2012;96:1074-83.

11. Gupta SC, Tyagi AK, Deshmukh-Taskar P, Hinojosa M, Prasad S, Aggarwal BB. Downregulation of tumor necrosis factor and other proinflammatory biomarkers by polyphenols. Arch Biochem Biophys. 2014;559:91-9.

12. Zhu L, Chen J, Tan J, Liu X, Wang B. Flavonoids from Agrimonia pilosa Ledeb. Free radical scavenging and DNA oxidative damage protection activities and analysis of bioactivity-structure relationship based on molecular and electronic structures. Molecules. 2017;22:195. 
13. Santos TN, Costa G, Ferreira JP, Liberal J, Francisco V, Paranhos A, et al. Antioxidant, anti-linflammatory, and analgesic activities of Agrimonia eupatoria L. infusion. Evid-based Compl Alt. 2017;8309894;2017.

14. Ivanova D, Vankova D, Nashar M. Agrimonia eupatoria tea consumption in relation to markers of inflammation, oxidative status and lipid metabolism in healthy subjects. Arch Physiol Biochem. 2013;119:32-7.

15. Copland A, Nahar L, Tomlinson CTM, Hamilton V, Middleton M, Kumarasamy $Y$, et al. Antibacterial and free radical scavenging activity of the seeds of Agrimonia eupatoria. Fitoterapia. 2003;74:133-5.

16. Ivanova D, Tasinov O, Vankova D, Kiselova-Kaneva Y. Antioxidative potential of Agrimonia eupatoria L. Medicine. 2011;1:20-4.

17. Granica S, Kluge H, Horn G, Matkowski A, Kiss AK. The phytochemical investigation of Agrimonia eupatoria L. and Agrimonia procera Wallr. as valid sources of Agrimoniae herba--the pharmacopoeial plant material. J Pharmaceut Biomed. 2015;114:272-9.

18. Gräber T, Kluge H, Granica S, Horn G, Brandsch C, Stangl Gl. Studies on the health impact of Agrimonia procera in piglets. BMC Vet Res. 2014;10:210.

19. Kaper JB, Nataro JP, Mobley HL. Pathogenic Escherichia coli. Nat Rev. 2004;2: $123-40$

20. Nagy B, Fekete PZ. Enterotoxigenic Escherichia coli in veterinary medicine. Int J Med Microbiol. 2005;295:443-54.

21. Cho JH, Zhao PY, Kim $I H$. Probiotics as a dietary additive for pigs: a review. J Anim Vet Adv. 2011;10:2127-34

22. Madsen K, Cornish A, Soper P, McKaigney C, Jijon H, Yachimec C, et al. Probiotic bacteria enhance murine and human intestinal epithelial barrier function. Gastroenterology. 2001;121:580-91.

23. Fuller R. A review: probiotics in man and animals. J Appl Bacteriol. 1989;66: 365-78

24. Miguel MG. Antioxidant and anti-inflammatory activities of essential oils: a short review. Molecules. 2010;15:9252-87.

25. Manzanilla EG, Perez JF, Martin M, Kamel C, Baucells F, Gasa J. Effect of plant extracts and formic acid on the intestinal equilibrium of early-weaned pigs. J Anim Sci. 2004;82:3210-8.

26. Hernández F, Madrid J, García V, Orengo J, Megias MD. Influence of two plant extracts on broilers performance, digestibility, and digestive organ size. Poult Sci. 2004;83:169-74.

27. Gonthier MP, Donovan JL, Texier O, Felgines C, Remesy C, Scalber A. Metabolism of dietary procyanidins in rats. Free Radical Bio Med. 2003;35: 837-44

28. Manach C, Williamson G, Morand C, Scalbert A, Rémésy C. Bioavailability and bioefficacy of polyphenols in humans. I. Review of 97 bioavailability studies. Am J Clin Nutr. 2005;81:230-42.

29. Tsang C, Auger C, Mullen W, Bornet A, Rouanet JM, Crozier A, et al. The absorption, metabolism and excretion of flavan-3-ols and procyanidins following the ingestion of a grape seed extract by rats. Brit J Nutr. 2005;94: 170-81.

30. Hara H, Orita N, Hatano S, Ichikawa H, Hara Y, Matsumoto N, et al. Effect of tea polyphenols on fecal flora and fecal metabolic products of pigs. J Vet Med Sci. 1995:57:45-9.

31. Ishihara N, Chu DC, Akachi S, Juneja LR. Improvement of intestinal microflora balance and prevention of digestive and respiratory organ diseases in calves by green tea extracts. Livest Prod Sci. 2001;68:217-29.

32. Hara Y. Influence of tea catechins on the digestive tract. J Cell Biochem. 1997;67:52-8.

33. Bruins MJ, Vente-Spreeuwenberg MAM, Smits CH, Frenken LGJ. Black tea reduces diarrhoea prevalence but decreases growth performance in enterotoxigenic Escherichia coli-infected post-weaning piglets. J Anim Physiol An N. 2011;95:388-98

34. Bruins MJ, Cermak R, Kiers JL, van Dder Meulen J, van Amelsvoort JMM, van Klinken BJW. In vivo and in vitro effects of tea extracts on enterotoxigenic Escherichia coli-induced intestinal fluid loss in animal models. J Pediatr Gastr Nutr. 2006:43:459-69.

35. Wichtl H. Teedroge und Phytopharmaka: herbal drugs and phytopharmaceuticals: a handbook for practice on a scientific basis $e$ Stuttgart: CRC Press; 2004.

36. Lee HC, Jenner AM, Low CS, Lee YK. Effect of tea phenolics and their aromatic fecal bacterial metabolites on intestinal microbiota. Res Microbiol. 2006:157:876-84

37. Funatogawa K, Hayashi S, Shimomura H, Yoshida T, Hatano T, Ito H, et al. Antibacterial activity of hydrolyzable tannins derived from medicinal plants against Helicobacter pylori. Microbiol Immunol. 2004;48:251-61.
38. Kasai S, Watanabe S, Kawabata J, Tahara S, Mizutani J. Antimicrobial catechin derivatives of Agrimonia pilosa. Phytochemistry. 1992;31:787-9.

39. Klingspor S, Bondzio A, Martens H, Aschenbach JR, Bratz K, Tedin K, et al. Enterococcus faecium NCIMB 10415 modulates epithelial integrity, heat shock protein, and proinflammatory cytokine response in intestinal cells. Mediat Inflamm. 2015;2015:304149.

40. Cavalcanti E, Vadrucci E, Delvecchio FR, Addabbo F, Bettini S, Liou R, et al. Administration of reconstituted polyphenol oil bodies efficiently suppresses dendritic cell inflammatory pathways and acute intestinal inflammation. PLoS One. 2014;9:e88898.

41. Sangiovanni E, Fumagalli M, Vrhovsek U, Colombo E, Brunelli C, Gasperotti $M$, et al. In vitro anti-inflammatory activity of Fragaria spp. in human gastric epithelial cells. In: Farmacognosia: nuove opportunità terapeutiche dal mondo vegetale; 2014

42. Erlejman AG, Verstraeten SV, Fraga CG, Oteiza PI. The interaction of flavonoids with membranes: potential determinant of flavonoid antioxidant effects. Free Radic Res. 2004;38:1311-20.

43. Erlejman AG, Jaggers G, Fraga CG, Oteiza PI. TNFalpha-induced NF-kappaB activation and cell oxidant production are modulated by hexameric procyanidins in Caco-2 cells. Arch Biochem Biophys. 2008;476:186-95.

44. Chohan M, Naughton DP, Jones L, Opara El. An investigation of the relationship between the anti-inflammatory activity, polyphenolic content, and antioxidant activities of cooked and in vitro digested culinary herbs. Oxidative Med Cell Longev. 2012;2012:627843.

45. Gao CY, Xu TT, Zhao QJ, Li CL. Codon optimization enhances the expression of porcine beta-defensin-2 in Escherichia coli. Genet Mol Res. 2015;14:4978-88.

46. Han $F$, Zhang $H$, Xia $X$, Xiong $H$, Song $D$, Zong $X$, et al. Porcine $\beta$-defensin 2 attenuates inflammation and mucosal lesions in dextran sodium sulfateinduced colitis. J Immunol. 2015;194:1882-93.

47. Liu Y, Song M, Che TM, Bravo D, Pettigrew JE. Anti-inflammatory effects of several plant extracts on porcine alveolar macrophages in vitro. J Anim Sci. 2012;90:2774-83.

48. Palsson-McDermott EM, O'Neill LA. Signal transduction by the lipopolysaccharide receptor, toll-like receptor-4. Immunology. 2004;113: 153-62.

49. Balaji R, Wright KJ, Hill CM, Dritz SS, Knoppel EL, Minton JE. Acute phase responses of pigs challenged orally with Salmonella typhimurium. J Anim Sci. 2000;78:1885-91.

50. Liu YL, Li DF, Gong LM, Yi GF, Gaines AM, Carroll JA. Effects of fish oil supplementation on the performance and the immunological, adrenal, and somatotropic responses of weaned pigs after an Escherichia coli lipopolysaccharide challenge1. J Anim Sci. 2003;81:2758-65.

51. Zannelli ME, Touchette $\mathrm{KJ}$, Allee $\mathrm{GL}$, Matteri RL, Beausang LA, Luchene $L$, et al. A comparison of the immunological response to lipopolysaccharide (LPS) versus E. coli challenge in the weaned pig. J Anim Sci. 2000;78:77.

52. Johnson RW. Inhibition of growth by pro-inflammatory cytokines: an integrated view. J Anim Sci. 1997:75:1244-55.

53. Webel DM, Finck BN, Baker DH, Johnson RW. Time course of increased plasma cytokines, cortisol, and urea nitrogen in pigs following intraperitoneal injection of lipopolysaccharide. J Anim Sci. 1997;75:1514-20.

54. Carroll JA, Gaines AM, Spencer JD, Allee GL, Kattesh HG, Roberts MP, et al. Effect of menhaden fish oil supplementation and lipopolysaccharide exposure on nursery pigs. I. Effects on the immune axis when fed diets containing spray-dried plasma. Domest Anim Endocrin. 2003;24:341-51.

55. Stelter K, Frahm J, Paulsen J, Berk A, Kleinwächter M, Selmar D, et al. Effects of oregano on performance and immunmodulating factors in weaned piglets. Arch Anim Nutr. 2013;67:461-76

56. Kluger MJ, Ringler HD, Anver MR. Fever and survival. Science. 1975;188: 166-8.

57. Kluger MJ, Rothenburg BA. Fever and reduced iron: their interaction as a host defense response to bacterial infection. Science. 1979;203:374-6.

58. Green $\mathrm{MH}$, Vermeulen $\mathrm{CW}$. Fever and the control of gram-negative bacteria. Res Microbiol. 1994;145:269-72

59. Chang CP, Chang JY, Wang FY, Chang JG. The effect of chinese medicinal herb Zingiberis rhizoma extract on cytokine secretion by human peripheral blood mononuclear cells. J Ethnopharmacol. 1995:48:13-9.

60. Barak V, Halperin T, Kalickman I. The effect of Sambucol, a black elderberrybased, natural product, on the production of human cytokines: I. Inflammatory cytokines. Eur Cytokine Netw. 2001;12:290-6.

61. Han X, Shen T, Lou H. Dietary polyphenols and their biological significance. Int J Mol Sci. 2007;8:950-88. 
62. Miyamoto K, Kishi N, Koshiura R. Antitumor effect of agrimoniin, a tannin of Agrimonia pilosa Ledeb., on transplantable rodent tumors. JPN J Pharmacol. 1987:43:187-95.

63. Hoffmann J, Casetti F, Bullerkotte U, Haarhaus B, Vagedes J, Schempp CM, et al. Anti-inflammatory effects of agrimoniin-enriched fractions of Potentilla erecta. Molecules. 2016;21:792.

64. Kong XF, Wu GY, Liao YP, Hou ZP, Liu HJ, Yin FG, et al. Effects of Chinese herbal ultra-fine powder as a dietary additive on growth performance, serum metabolites and intestinal health in early-weaned piglets. Livest Sci. 2007;108:272-5

65. Hanczakowska E, Swiatkiewicz M. Effect of herbal extracts on piglet performance and small intestinal epithelial villi. Czech J Anim Sci. 2012;57: 420-9.

66. Petrovic V, Marcincak S, Popelka P, Simkova J, Martonova M, Buleca J, et al. The effect of supplementation of clove and agrimony or clove and lemon balm on growth performance, antioxidant status and selected indices of lipid profile of broiler chickens. J Anim Physiol An N. 2012:96:970-7.

67. Grochowski DM, Skalicka-Woźniak K, Orhan IE, Xiao J, Locatelli M, Piwowarski JP, et al. A comprehensive review of agrimoniin. Ann N Y Acad Sci. 2017; 1401:166-80.

68. Cheng G, Hao H, Xie S, Wang X, Dai M, Huang L, et al. Antibiotic alternatives: the substitution of antibiotics in animal husbandry? Front Microbiol. 2014;5:217.

69. Pfaffl MW. A new mathematical model for relative quantification in real-time RT-PCR. Nucleic Acids Res. 2001;29:e45.

70. Gesellschaft für Ernährungsphysiologie. Recommendations for energy and nutrients supply of pigs. 1st ed. Frankfurt: DLG-Verlag; 2006.

Ready to submit your research? Choose BMC and benefit from:

- fast, convenient online submission

- thorough peer review by experienced researchers in your field

- rapid publication on acceptance

- support for research data, including large and complex data types

- gold Open Access which fosters wider collaboration and increased citations

- maximum visibility for your research: over $100 \mathrm{M}$ website views per year

At $\mathrm{BMC}$, research is always in progress.

Learn more biomedcentral.com/submissions 